\title{
MORPHOLOGICAL VARIATION OF EARLY DAYS TO FLOWERINGON LOCAL RICE ACCESSIONS COLLECTED FROM PONOROGO
}

\author{
Niken Trisnaningrum and Alfu Laila \\ Department of Agrotechnology, Faculty of Science and Technology \\ University of Darussalam Gontor \\ Email: alfulaila@unida.gontor.ac.id
}

\begin{abstract}
ABSTRAK
Padi lokal merupakan sumber plasma nutfah yang berperan penting untuk meningkatkan kualitas padi. Salah satu sifat penting untuk meningkatkan sifat kultivar padi adalah waktu berbunga. Ponorogo merupakan salah satu pusat produksi padi dimana para petani menggunakan padi lokal berbunga awal atau memiliki masa vegetatif yang pendek sebagai bahan tanam. Terdapat 9 aksesi hasil eksplorasi padi lokal berbunga cepat. Umur berbunga berkisar 51 - 91 hari setelah tanam. Terdapat keragaman morfologi yang diamati yakni tinggi tanaman, jumlah daun, jumlah anakan, jumlah malai, jumlah gabah per malai, waktu berunga, panjang dan lebar gabah, dan bobot 100 gabah. Dari hasil analisis dendogram morfologi terbagi menjadi 3 kelompok pada tingkat kemiripan morfologi yang tinggi yakni 0.88. Informasi tentang similaritas dan pengelompokan akan memudahkan pemulia tanaman untuk memilih tetua dalam perancangan program persilangan tanaman.
\end{abstract}

Kata kunci: Padi; Plasma nutfah; Ponorogo; Waktu berbunga.

\section{ABSTRACT}

Morphological Variation of Early Days to Floweringon Local Rice Accessions Collected from Ponorogo, Local rice germplasm may play an important role in improving rice quality. One of the important to improve rice cultivar trait is days to flowering. Ponorogo is one of district of center rice production area where the farmers cultivate local rice varieties whichis early days to flowering or short vegetative phase. Exploration of local early days to flowering rice accessions in Ponorogo resulted in 9 accessions. Flowering times ranged 51 to 91 days after sowing. Based on morphological variation, there were variation of plant height, number of leaves, number of tiller, number of panicle, number of grains per panicle, flowering time, grain size and weight of 100 grains. Morphological dendrogram made possible to identify three groups at high similarity of morphology 0.88 . The information of genetic similarity and cluster analysis will guide breeder in selecting parents for crossing program.

Keywords: Early flowering time; Germplasm; Ponorogo; Rice. 


\section{INTRODUCTION}

Rice belongs to the genus Oryza within the Poaceae family. The Oryza genus has given a rise to rice (Oryza sativa L.), a major source of nutrition for about two-third of mankind (Vaughan et al., 2003). There are three subspecies of Oryza sativa cultivated around the world, e.g japonica, indica and javanica. In Indonesia, the rice cultivated belongs to most of subspecies javanica. It has been different traits to japonica and indica. There are about 14.12 million hectares of rice land, which provide around 75.4 million tons of rough rice annually(BPS, 2016).

Improving rice cultivars is being developed in many countries (Wang et al, 2013; Torres and Henry, 2016). Some of researches reported that improvement of rice trait aimed to increase the high yield with tolerance into abiotic (Swain et al., 2017; Zu et al., 2017) and biotic (Abdullah, 2006), resistance to pest and diseases (Ladja and Widiarta, 2012; Arunakamari et al, 2016; Wu et al., 2017). One of the important to improve rice traits is days to flowering (Utami et al, 2011). In rice breeding, the effect of flowering time genes become major interest since one of flowering time controlling gene, Ghd7, can control the number of grain per panicle (Pushphakumari and Geekiyanage, 2017).

To conduct rice breeding in early days to flowering trait, exploration and characterization of rice germplasm are necessary.Local rice germplasm may play an important role in improving rice quality. In Indonesia has many local rice varieties with special morphological traits as genetic resources. Unfortunately, diversity of local rice cultivars decreases caused by most of the farmers cultivate leading rice cultivars only as consumer preferred (Afza, 2016; Bakhtiar et al, 2011).

Ponorogo is one of center rice production area. In Ponorogo, the farmers cultivate local rice varieties with early days to flowering trait. The farmers cultivate early days to flowering rice varieties between rice - rice planting time or on
February - March. Ponorogo still have isolated areas that the farmers still plant local rice variety. This local varieties were known having good taste, early days to flowering, and high characteristic that can be potential traits to develop.

In this case, study of morphological variation is important for conserving, evaluating, and utilizing genetic resources; and for studying the diversity of prebreeding and breeding germplasm for developing early days to flowering on rice. Study of morphological variation is necessary for identifying diverse parental combination with high variation for selection.

\section{Method \\ Exploration of rice germplasm}

Exploration of rice germplasm was carried out from February to March 2017 in Ponorogo, East Java. The exploration was conducted where rice farmers cultivate local rice as rice germplasms source. The data recorded of early days to flowering rice varieties in the area. Local rice seed with early days to flowering was collected for field experiment.

\section{Field Experiment}

Local rice accessions with early days to flowering collected from Ponorogo were grown at greenhouse, Department of Agrotechnology, Faculty of Science and Technology, University of Darussalam Gontor, Ponorogo, East Java, Indonesia. The experiment was laid out completely randomized design with 11 replications. The seed were sown at pot and the water maintained at field capacity level. Manual weeding, pest and disease management was applied at regular intervals. Organic fertilizer application was applied at 2 weeks, 4 weeks and 6 weeks after sown.

The rice germplasm was observed of morphological traits. The details of data recorded of plant high, number of tiller, number of panicle, days to flowering, harvest time, number of grains per panicle, grain size and weight of 100 grains. 
The statistical differences among accessions with morphological traits were analyzed from ANOVA test, followed by Duncan New Multiple's Range Test (DMRT). A clustering of observations was performed to classify rice cultivar traits into groups. It was applied using the squared of Pearson distance between observations (the sum of square distances divided by variances).

\section{RESULTS AND DISCUSSION}

Table 1. Nine local rice accessions collected from Ponorogo

\begin{tabular}{l|l|l|l}
\hline \multicolumn{1}{c|}{ Code Name } & \multicolumn{1}{c|}{ Local Name } & \multicolumn{1}{c}{ Sub district } & \multicolumn{1}{c}{ Species } \\
\hline M1 & Beras Merah & Mlarak & Oryza nivara \\
\hline M2 & Mlarak 1 & Mlarak & Oryza sativa \\
\hline M3 & Malihan Ketan & Mlarak & Oryza sativa \\
\hline M4 & Mlarak 2 & Mlarak & Oryza sativa \\
\hline S1 & Jaya & Siman & Oryza sativa \\
\hline S2 & Ciherang Kuning & Siman & Oryza sativa \\
\hline S3 & Philips & Siman & Oryza sativa \\
\hline S4 & Ketan Lokal & Siman & Oryza sativa \\
\hline S5 & Legowo & Siman & Oryza sativa \\
\hline
\end{tabular}

There are different seedbed areas of rice due to irrigation system in Ponorogo. The area with basin irrigation system has seedbed area in different location with wetlands. The farmers have been sowing with modern system and cultivating leading rice cultivars. In other areas, the farmers have seedbed and cultivation area of rice in one location. Those areas can find in Mlarak and Siman. The farmers use border irrigation system so that they can manage the water for seedbed. The farmers cultivate local rice with traditional cultivation. Nine accessions of local rice were collected from sub district Mlarak and Siman areas (Table 1). Four accessions were collected from Mlarak while five accessions were collected from Siman. Local name was called by farmers that might be it was different name in other area. Four accessions collected from Mlarak consisted of M1 (Beras Merah), M2 (Mlarak 1), M3 (Malihan Ketan) and M4 (Mlarak 2). Five accessions collected from Siman were S1 (Jaya), S2 (Ciherang Kuning), S3 (Philips), S4 (Ketan Lokal) and S5 (Legowo).

Table 2. Vegetative traits of nine local rice accessions collected from Ponorogo

\begin{tabular}{l|l|l|l|l|l|l|l}
\hline \multicolumn{1}{c|}{ Code Name } & \multicolumn{1}{|c|}{ Local Name } & \multicolumn{2}{c|}{ Plant height $\mathbf{( c m})$} & \multicolumn{2}{c|}{ Number of leaves } & \multicolumn{2}{c}{ Number of tiller } \\
\hline M1 & Beras Merah & 110.0 & $\mathrm{~b}$ & 29.8 & $\mathrm{bc}$ & 7.6 & $\mathrm{a}$ \\
\hline M2 & Mlarak 1 & 121.4 & $\mathrm{a}$ & 33.8 & $\mathrm{~b}$ & 7.9 & $\mathrm{a}$ \\
\hline M3 & Malihan Ketan & 120.3 & $\mathrm{a}$ & 23.7 & $\mathrm{~cd}$ & 6.0 & $\mathrm{~cd}$ \\
\hline M4 & Mlarak 2 & 99.8 & $\mathrm{c}$ & 25.5 & $\mathrm{~cd}$ & 6.5 & $\mathrm{cb}$ \\
\hline S1 & Jaya & 118.5 & $\mathrm{a}$ & 31.4 & $\mathrm{bc}$ & 6.1 & $\mathrm{cbd}$ \\
\hline S2 & Ciherang Kuning & 104.8 & $\mathrm{bc}$ & 51.4 & $\mathrm{a}$ & 7.8 & $\mathrm{~b}$ \\
\hline S3 & Philips & 109.0 & $\mathrm{~b}$ & 29.7 & $\mathrm{bc}$ & 8.1 & $\mathrm{a}$ \\
\hline S4 & Ketan Lokal & 104.7 & $\mathrm{bc}$ & 18.9 & $\mathrm{~d}$ & 4.6 & $\mathrm{~d}$ \\
\hline S5 & Legowo & 92.6 & $\mathrm{~d}$ & 28.9 & $\mathrm{bc}$ & 7.0 & $\mathrm{cb}$ \\
\hline
\end{tabular}

Values reported were mean of eleven replications. Means in the same column with different letter are statistically different (Duncan New Multiple's Range Test, $\mathrm{P}<0.05)$

Plant height, number of leaves and number of tiller (Table 2) showed variation among each accession. The highest plant is
M2 (Mlarak 1) (121.4 cm), S1 (Jaya) (118.5 $\mathrm{cm})$, and M3 (Malihan Ketan) $(120.3 \mathrm{~cm})$ while the shortest is M4 (Mlarak) $(99.8 \mathrm{~cm})$. 
Previous research showed that plant height variation of rice line resulted crossing among Javanica, Japonica and Indica was125.70 $\pm 16,42$ cm (Dewi et al., 2009). S2 (Ciherang kuning) showed the most of number of leaves (51.4 $\mathrm{cm}$ ) while S4 (Ketan Local) showed the least of number of leaves (18.9).M2 (Mlarak 1),
M1(Beras Merah) and S3 (Philips)showed the most of number of tillers(7.6; 7.9 and 8.1). S4 (Ketan Local) showed the least in both number of leaves $(18.9 \mathrm{~cm})$ and number of tiller (4.6). Local 'gogo' rice from Aceh varied from10 to 13 tillers per plant (Syahril, 2017). It showed that number of tiller of local rice from Ponorogo is lower than the others.

Table 3. Generative traits of nine local rice accessions collected from Ponorogo

\begin{tabular}{l|l|l|l|l|l|l|l|l|l}
\hline $\begin{array}{c}\text { Code } \\
\text { Name }\end{array}$ & \multicolumn{1}{|c|}{ Local Name } & \multicolumn{2}{|c|}{$\begin{array}{c}\text { Flowering time } \\
\text { (days to flowering) }\end{array}$} & $\begin{array}{c}\text { Number of } \\
\text { panicle }\end{array}$ & \multicolumn{2}{c|}{$\begin{array}{c}\text { Number of grains } \\
\text { per panicle }\end{array}$} & \multicolumn{2}{c}{$\begin{array}{c}\text { Weight of 100 } \\
\text { grains (gr) }\end{array}$} \\
\hline M1 & Beras Merah & 78.0 & $\mathrm{c}$ & 7.0 & $\mathrm{ab}$ & 155.6 & $\mathrm{cde}$ & 2.132 & $\mathrm{~b}$ \\
\hline M2 & Mlarak 1 & 81.0 & $\mathrm{~d}$ & 5.7 & $\mathrm{bc}$ & 148.4 & $\mathrm{de}$ & 2.447 & $\mathrm{ab}$ \\
\hline M3 & Malihan Ketan & 81.0 & $\mathrm{~d}$ & 6.7 & $\mathrm{abc}$ & 212.7 & $\mathrm{ab}$ & 2.747 & $\mathrm{a}$ \\
\hline M4 & Mlarak 2 & 51.0 & $\mathrm{a}$ & 8.3 & $\mathrm{a}$ & 126.6 & $\mathrm{e}$ & 2.386 & $\mathrm{ab}$ \\
\hline S1 & Jaya & 90.0 & $\mathrm{e}$ & 6.3 & $\mathrm{abc}$ & 189.0 & $\mathrm{bc}$ & 2.595 & $\mathrm{a}$ \\
\hline S2 & Ciherang Kuning & 69.0 & $\mathrm{~b}$ & 7.7 & $\mathrm{ab}$ & 225.0 & $\mathrm{a}$ & 2.061 & $\mathrm{~b}$ \\
\hline S3 & Philips & 51.0 & $\mathrm{a}$ & 6.0 & $\mathrm{bc}$ & 153.9 & $\mathrm{cde}$ & 2.542 & $\mathrm{a}$ \\
\hline S4 & Ketan Lokal & 51.0 & $\mathrm{a}$ & 4.7 & $\mathrm{c}$ & 169.8 & $\mathrm{~cd}$ & 2.557 & $\mathrm{a}$ \\
\hline S5 & Legowo & 81.4 & $\mathrm{~d}$ & 5.7 & $\mathrm{bc}$ & 148.4 & $\mathrm{de}$ & 2.447 & $\mathrm{ab}$ \\
\hline
\end{tabular}

Values reported were mean of eleven replications. Means in the same column with different letter are statistically different (Duncan New Multiple's Range Test, $\mathrm{P}<0.05$ )

Generative traits variation showed in table 3. Flowering time showed variation among each accession. Earliest days to flowering was identified in three accessions which was 51 days to flowering. They were S3 (Philips), S4 (Ketan Lokal)and M4 (Mlarak 2). They were followed by S2 (Ciherang Kuning) which was 69 days, then M1 (Beras Merah) 78 days to flowering. S5 (Legowo), M2 (Mlarak 1) and M4 (Mlarak 2) showed 81 days to flowering. S1 (Jaya) showed the latest flowering (90 days to flowering). Previous research showed that flowering time of rice line resulted crossing among Javanica, Japonica and Indicawas $85.8 \pm 7.2$ days after sowing (Dewi et al., 2009). The earliest flowering of 'gogo' local rice in Aceh showed by Sigedul at 101 days after planting (Syahril, 2017) whereas in Banten showed by Ketan Mayang at 84 days after planting (Mulyaningsih and Indriyani, 2014). In West Sumatera, flowering time of local rice varied from 73.33 to 92 days after plant (Putih et al., 2011). In Sri Lanka, there was variation of flowering time of traditional rice accession. It ranged from 58 to $200+$ days to flowering (Rathnathunga et al., 2016). It indicated that the local rice accessions from Ponorogo is most of earliest flowering than the previous researches. All of nine of local rice accessions were potential parental to be further selected for developing early days to flowering cultivar.

M2 (Mlarak 2)showed the most number of panicle (8.3 panicles), while S2 (Ciherang Kuning)showed the most number of grains per panicle (225 grains).Number of grains per panicle of local rice varieties of tidal swamp area in South Kalimantan varied from 96 to 215 grains per panicle (Wahdah et al., 2012). Other research showed that number of grain per panicle of local rice in West Sumatera ranged from 162.35 to 193.03 grains (Putih et al., 2011). M3 (Malihan Ketan) showed the heaviest of weight of 100 grains (2.747 grams). Previous research showed that weight of 100 grains of rice line resulted crossing among Javanica, Japonica and Indicawas $2.032 \pm 0.693$ grams (Dewi et al., 2009). Weight of 100 grams of local rice in previous research ranged from 1.91 to 3.54 grams (Mulyaningsih and Indriyani, 2014). 
NIKEN TRISNANINGRUM AND ALFU LAILA MORPHOLOGICAL VARIATION OF EARLY DAYS TO FLOWERINGON LOCAL RICE ACCESSIONS COLLECTED FROM PONOROGO

Table 4. Rice grain shape and size traits of nine accessions collected from Ponorogo

\begin{tabular}{l|l|l|l|l|l|l|l}
\hline $\begin{array}{c}\text { Code } \\
\text { Name }\end{array}$ & Local Name & \multicolumn{2}{|c|}{ Grain length $(\mathbf{m m})$} & \multicolumn{2}{c|}{ Grain width (mm) } & \multicolumn{2}{c}{ Rasio (length : width) } \\
\hline M1 & Beras Merah & 6.500 & c & 2.496 & b & 2.604 & medium \\
\hline M2 & Mlarak 1 & 9.140 & b & 3.020 & a & 3.029 & long \\
\hline M3 & Malihan Ketan & 8.770 & bc & 3.020 & a & 2.907 & medium \\
\hline M4 & Mlarak 2 & 9.308 & b & 2.526 & b & 3.700 & long \\
\hline S1 & Jaya & 8.830 & bc & 3.088 & a & 2.874 & medium \\
\hline S2 & Ciherang Kuning & 10.294 & a & 2.224 & c & 4.647 & long \\
\hline S3 & Philips & 9.552 & b & 2.458 & b & 3.886 & long \\
\hline S4 & Ketan Lokal & 8.156 & b & 2.938 & a & 2.780 & medium \\
\hline S5 & Legowo & 9.286 & b & 3.014 & a & 3.084 & long \\
\hline
\end{tabular}

Values reported were mean of eleven replications. Means in the same column with different letter are statistically different (Duncan New Multiple's Range Test, $\mathrm{P}<0.05$.

Variation of grain length ranged from 6.5 to $10.294 \mathrm{~mm}$ while width grain ranged from 2.224 to $3.020 \mathrm{~mm}$ (Table 4). From previous research, grain length of IR 36 (Indica) was 8.84 $\mathrm{mm}$ while the width grain was $2.42 \mathrm{~mm}$. In the others, grain length of Japonica was $7.6 \mathrm{~mm}$ while width grain was $3.12 \mathrm{~mm}$ (Su et al., 2012).
Ratio of grain length and width divided all accessions into two groups. There were medium and long grain. Figure 1 showed that the shape of each accession. Medium grain showed by S1 (Jaya), M1 (Beras Merah), S4 (Ketan Lokal), and M3(Malihan Ketan). Long grain included S2 (Ciherang Kuning), S3 (Philips), S5 (Legowo), M2 (Mlarak 1) and M4 (Mlarak 2).

A.

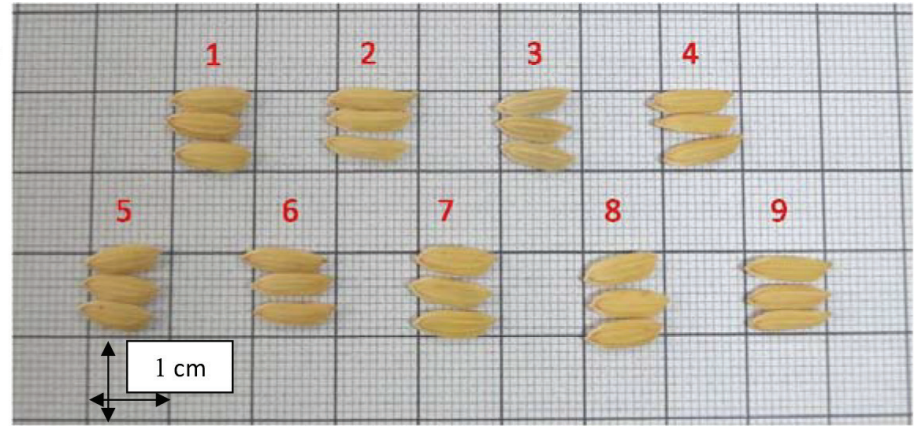

B.

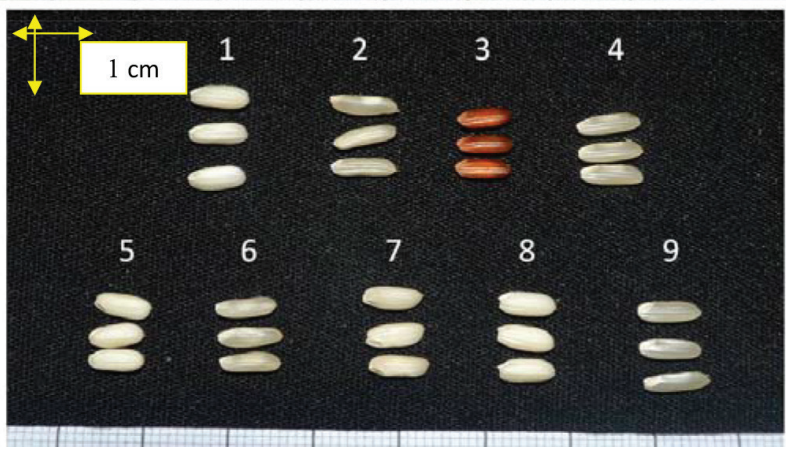

Figure 1

Rice grains shape of all varieties that be explored in Siman and Mlarak. The varieties include Jaya/S1 (1), Ciherang Kuning/S2 (2), Beras Merah/M1 (3), Philips/S3 (4), Ketan lokal/S4 (5), Legowo/S5 (6), Mlarak 1/M2 (7), Malihan ketan/M3 (8), Mlarak 2/M4 (9). A. Dehusk rice grains. B. Rice grains 


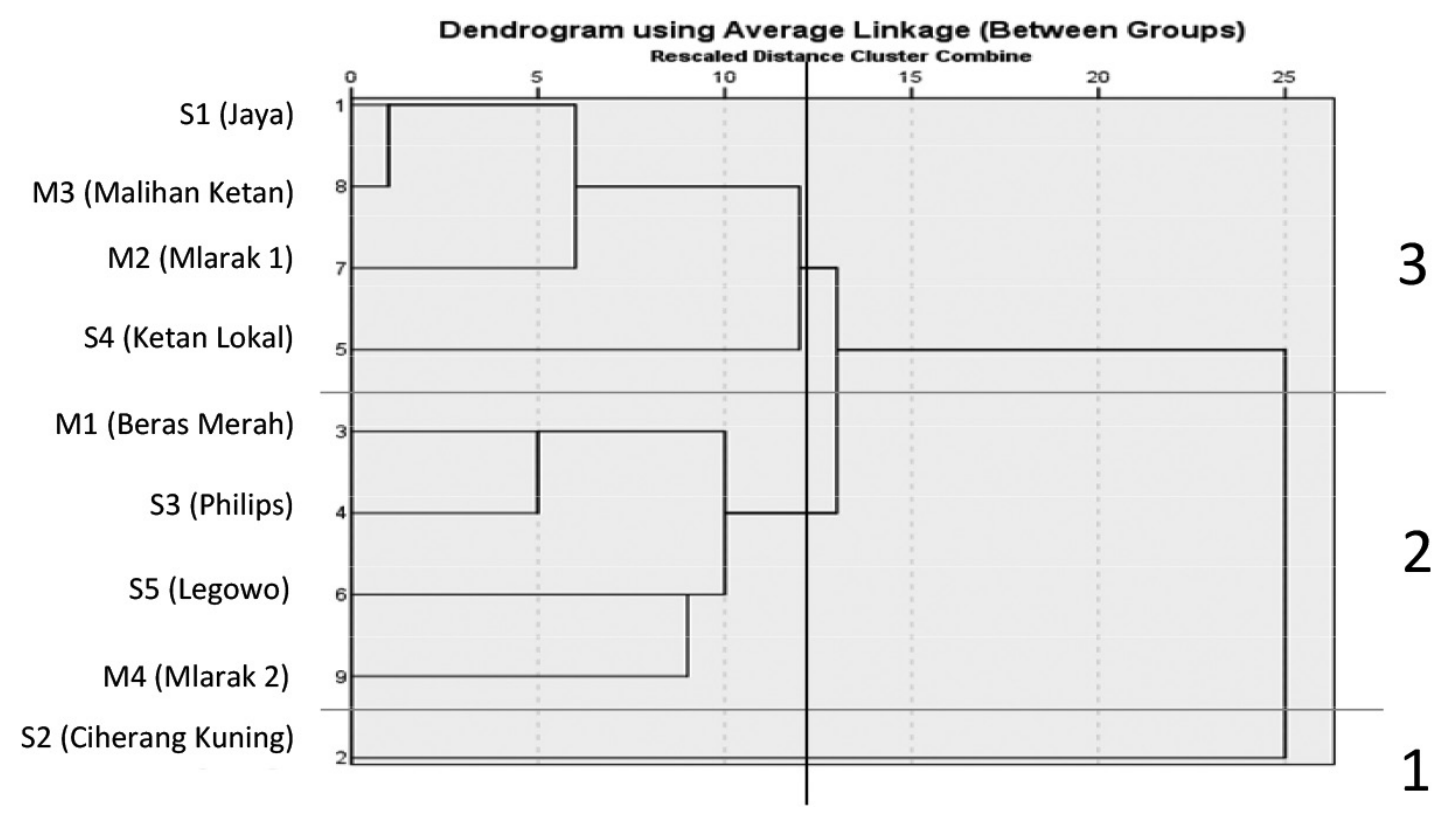

Figure 2 .

Morphological dendogram using average linkage between each accession

Figure 2 showed the morphological dendogram based on average distance among accessions. The dendogram made possible to identify three groups at similarity 0.88 . First groups consisted of S1(Jaya), M3 (Malihan Ketan,), M2(Mlarak 1) and S4 (Ketan Lokal). Second group was made byM1 (Beras Merah), S3 (Philips), S5 (Legowo) and M4 (Mlarak 2). Third group was most characterized of S2 (Ciherang Kuning). It showed that the similarity of rice germplasm did not influenced by geographic or area. Based on survey data,S2 (Ciherang Kuning)originated Sumatra, so the accession showedsmallest coefficient of similarity.It means thatS2 (Ciherang Kuning)showed far distance of genetic similarity with the others.

Table 5. Morphological values of nine rice local accessions for each cluster

\begin{tabular}{l|ll|ll|ll}
\hline \multicolumn{1}{c|}{ Traits } & \multicolumn{2}{c|}{ Cluster 1 } & \multicolumn{3}{c|}{ Cluster 2 } & \multicolumn{2}{c}{ Cluster 3 } \\
\hline Plant height (cm) & 116.2 & a & 104.8 & b & 102.8 & b \\
\hline Number of leaves & 26.9 & a & 51.4 & b & 28.4 & a \\
\hline Number of tillers & 6.1 & a & 7.8 & ab & 7.3 & a \\
\hline Flowering time (das) & 75.7 & a & 69.0 & a & 65.3 & a \\
\hline Number of panicle & 5.8 & b & 7.7 & a & 6.7 & ab \\
\hline Number of grains per panicle & 179.9 & b & 225.0 & a & 146.1 & c \\
\hline Weight of 100 grains & 2.5 & a & 2.0 & c & 2.3 & b \\
\hline Length of grains (mm) & 8.7 & c & 10.2 & a & 9.3 & b \\
\hline Width of grains (mm) & 3.0 & a & 2.2 & c & 2.6 & b \\
\hline Ratio length/width of grains & 2.8 & c & 4.6 & a & 3.5 & b \\
\hline
\end{tabular}

Table 5 was carried out for all variables to check the differences in their mean values among the groups obtained from the clustering stage. Group 1 was mostly characterized by the highest plant height, the most number of weight 100 grains, the shortest of grain length, the lightest of grain width and the lowest of length/width grain ratio. Group 
2 showed that most of leaves number, most of grain panicle number, the lightest of 100 grains weight, the longest of grains length, the shortest of width length and the highest of length/width grain ratio. Group 3 was formed by medium weight of 100 grains, length and width of grains and ration length/ with of grains. Based on yield component traits, it indicated that cluster 2 had the most of number of grains per panicle but the lightest of weight of 100 grains. In contrast, cluster 1 showed the heaviest of weight of 100 grains but medium of number of grains per panicle.

\section{CONCLUSION}

Exploration of local early days to flowering rice accessions in Ponorogo resulted in 9 accessions. Flowering times ranged 51 to 91 days to flowering. Based on morphological variation, there were variation of plant height, number of leaves, number of tiller, number of panicle, number of grains per panicle, flowering time, grain size and weight of 100 grains. Morphological dendogram made possible to identify three groups at high similarity of morphology 0.88 . The information of genetic similarity and cluster analysis will guide breeder in selecting parents for crossing program.

\section{BIBLIOGRAPHY}

Abdullah, B. 2006. Potensi padi liar sebagai sumber genetic dalam pemuliaan padi. Buletin Iptek Tanaman Pangan $1(2): 143-152$.

Afza, Higa. 2016. Role of conservation and characterization of genetic resources of red rice in plant breeding. Jurnal Litbang Pertanian 35 (3) : 143-153.

Arunakumari, K., C. V. Durgarani, V. Satturu, K. R. Sarikonda, P. D. R. Chittoor, B. Vutukuri, G. S. Laha, A. P. K. Nelli, S. Gattu, M. Jamal, A. Prasadbabu, S. Hajira, R. M. Sundaram. 2016. Marker-Assisted Pyramiding of Genes Conferring
Resistance Against Bacterial Blight and Blast Diseases into Indian Rice Variety MTU1010. Rice Science 23(6): 306-316. http://dx.doi. org/10.1016/j.rsci.2016.04.005

Badan Pusat Statistik. 2016. Luas Panen, Produksi dan Produktivitas Padi, 2009-2015. Badan Pusat Statistik. http:/ / www.bps.go.id/

Bakhtiar, Elly Kesumawati, Taufan Hidayat, Marai Rachmawati. 2011. Characterization of Aceh rice germplasm for developing adapted variety in acid soil. Agrista 15 (3) : 79 86.

Dwipa, I. Irfan Suliansyah. Auzar Syarif. Etti Swasti. 2014. Exploration and characterization of brown rice germplasm in west Sumatra. International Journal on Advance Science Engineering Information Technology 4 (3) : 34-37.

Iswari S. Dewi1 , Ari C. Trilaksana2 , Tri Koesoemaningtyas, dan Bambang S. Purwoko. Karakterisasi Galur Haploid Ganda Hasil Kultur Antera Padi. Buletin Plasma Nutfah 15 (1) : 1 $-12$.

Ladja, Fausiah T. dan I Nyoman Widiarta. 2012. Varietas Unggul Baru Padi untuk Mengantisipasi Ledakan Penyakit Tungro. Iptek Tanaman Pangan (7) 1: 18 - 24.

Mulyaningsih, Enung Sri and Sri Indrayani. 2014. Keragaman Morfologi dan Genetik Padi Gogo Lokal Asal Banten. (Phenotipe and genetic variation for Banten upland rice local cultivars). Jurnal Biologi Indonesia 10(1): 119-128.

Pushphakumari, W.H.D.U and Geekiyanage S. 2017. The effect of days to flowering on yield components of Sri Lankan rice Oryza sativa L. Proceeding of $72^{\text {nd }}$ ISERD International Conference, Bangkok, Thailand. 
Putih, Rida., Aswaldi Anwar, and Nur Ayu Rahma GR. 2011. Variabilitas Genetik Katakter Umur, Hasil, dan Komponen Hasil Beberapa Genotipe Padi Lokal (Oryza sativa L.) Sumatera Barat. Seminar Nasional : Reformasi Pertanian Terintegrasi Menuju Kedaulatan Pangan.

Rathnathunga, E. U. U., S. G. J. N. Senanayake, N. Dissanayake, S. Seneweera and S. Geekiyanage. 2016. Vegetative Growth and Yield Associated Flowering Time Variation in Sri Lankan Rice "Hondarawala". The Journal of Agricultural Sciences 11 (1) : $42-52$.

Suu, Tran Danh., Tran Thi Thu Hoai, Nguyen Thi Lan Hoa, Ha Minh Loan, Dinh Bach Yen, Toshihiro Kumamaru and Hikaru Satoh. Variation on Grain Quality in Vietnamese Rice Cultivars Collected from Central Vietnam. J. Fac. Agr., Kyushu Univ. 57 (2) : 365371.

Swain, Padmini., Anitha Ramana , S.P. Singh , Arvind Kumar. 2017. Breeding drought tolerant rice for shallow rainfed ecosystem of eastern India. Field Crops Research 209 : 168-178. http://dx.doi.org/10.1016/j. fcr.2017.05.007

Swapna, Simon and Korukkanvilakath Samban Shylaraj. 2017. Screening for Osmotic Stress Responses in Rice Varieties under Drought Condition. Rice Science 24(5): 253263. http://dx.doi.org/10.1016/j. rsci.2017.04.004

Syahril, Muhammad. 2017. Uji Adaptasi Beberapa Kultivar Padi Gogo Lokal Kabupaten Aceh Timur di Lahan
Keing Kebun Percobaan Universitas Samudra. AGROSAMUDRA4 (1) : 71 -76 .

Torres, Rolando O. and Amelia Henry. 2016. Yield stability of selected rice breeding lines and donors across conditions of mild to moderately severe drought stress. Field Crops Research : 1-9. http://dx.doi. org/10.1016/j.fcr.2016.09.011

Vaughan, D.A., Morishima, H., Kadowaki, K. 2003. Diversity in the Oryza genus. Current Opinion in Plant Biology 6 : 139 - 146.

Wahdah, Raihani., Bambang F. Langai, dan Trias Sitaresmi. 2012. Keragaman Karakter Varietas Lokal Padi Pasang Surut Kalimantan Selatan. Penelitian Pertanian Tanaman Pangan 31 (3): 158 $-165$.

Wang, Ying., Lubiao Zhang, Afif Nafisah, Linghua Zhu, Jianlong $\mathrm{Xu}$, Zhikang Li. 2013. Selection efficiencies for improving drought/salt tolerances and yield using introgression breeding in rice (Oryza sativa L.). The Crop Journal 1 : 134 - 142. http:/ / dx.doi.org/10.1016/j.cj.2013.07.006

Wu, Yunyu., Ling Yua, Ning Xiao, Zhengyuan Dai, Yuhong Li, Cunhong Pan, Xiaoxiang Zhang, Guangqing Liu, Aihong Li. 2017. Characterization and evaluation of rice blast resistance of Chinese indica hybrid rice parental lines. The Crop Journal :1 - 8. http:/ / dx.doi.org/10.1016/j.cj.2017.05.004

Zua, Xiaofeng., Yanke Lub, Qianqian Wang, Peifeng Chua, Wei Miaob, Huaqi Wanga, and Honggui La. 2017. A new method for evaluating the drought tolerance of upland rice cultivars. The Crop Journal : 1-11. http:/ / dx.doi. org/10.1016/j.cj.2017.05.002 